\title{
Creating a Library-Wide Collection Management Cycle: One Academic Library's Approach to Continuous Collection Assessment
}

\author{
Tricia Lantzy \\ Health Sciences \& Human Services Librarian \\ California State University San Marcos \\ plantzy@csusm.edu \\ (corresponding author) \\ Talitha Matlin \\ STEM Librarian \\ California State University San Marcos \\ tmatlin@csusm.edu \\ Judy Opdahl \\ Instruction \& Reference Librarian \\ California State University San Marcos \\ jopdahl@csusm.edu
}




\title{
Creating a library-wide Collection Management Cycle: One academic library's approach to continuous collection assessment
}

\begin{abstract}
Collections assessment in academic libraries has experienced a shift in recent years from projectbased models to continuous models that aim improve the responsivity of library collections to campus needs. This article reports on how one university library used a library committee with representation from across library departments to develop a holistic, on-going Collection Management Cycle. This newly created process evaluates the entire library collection over a five-year period and aligns with library reporting requirements for university program review to minimize additional workload and improve the impact of external reporting activities.
\end{abstract}

Keywords: collection assessment, collection management, collection evaluation, strategic planning, academic libraries

\section{Introduction}

Establishing formal processes to ensure continuous collection evaluation in academic libraries is becoming more and more necessary as library resource costs inflate without comparable increases in collections funds. While the values of caring for and building useful collections is not new territory for libraries, budgetary reductions that intensified during the 2008 recession as well as shifts in the makeup of library collections (online resources, patron driven acquisitions, etc.) have made it critical to manage the growing complexities of academic library collections and ensure that what is purchased is both used and valued. In a 2008 survey of librarians with collection development responsibilities in academic libraries, Wilde and Level report only $11 \%$ of respondents had a formal process for collection evaluation in place at their library (2011). By 
2016, a survey of 71 ARL Libraries reported 58\% had a process that was either entirely formal or somewhat formalized in their library (Harker \& Klein, 2016). ACRL's 2016 top trends in academic libraries acknowledges "There has been a remarkable shift to the incorporation and integration of more continuous, ongoing, flexible, and sustainable review of collections rather than ad-hoc project-based models" (ACRL Research Planning and Review Committee, 2016, p. 275). This dramatic increase in the development of formalized collection assessment processes reflects one way academic libraries are responding to pressures to create and demonstrate more value in their collections with less funding.

"Collection assessment" and "collection evaluation" will be used by the authors interchangeably to articulate the processes and procedures underlying how a library measures the usefulness or impact of a collection. Johnson provides a succinct definition of collection assessment as:

...the qualitative analysis of a library's collection. Qualitative analysis measures how well a library's collection supports a particular subject, how well the collection compares to that of another library, or the extent to which the library is purchasing the materials that users actually want. Collection assessment often makes decisions or judgments about a collection based on quantitative analysis. (2016, p. 489)

The term "collection management" will be used to broadly to include collection evaluation, budgetary allocation management, deselection processes, and various other library procedures vital to collection maintenance (e.g. inventory, stacks management, etc.). 
This article will review the current literature on collections assessment programs in academic libraries and share how one university library used a representative committee model approach to develop an on-going process for collections assessment. Moving from ad-hoc assessment of collections to continuous assessment represents a significant shift in culture for many academic libraries. The authors will highlight the unique process used to cultivate buy-in from across the library to support this change, including the role of the university library's strategic plan, the committee structure responsible for the development of the cycle, and the alignment with library reporting requirements for university program review.

\section{Literature Review}

The reasons behind why a library chooses to formally evaluate its collections often depend on the institutional and library context. While many goals of assessment are shared across libraries (such as the need to keep collections updated and relevant with a limited budget), individual libraries may have unique collection assessment goals due to differences in library types or institutional missions.

Duncan and O'Gara (2015) from the James Madison University libraries led the development of a collection assessment model to measure how well subject collections at the JMU libraries supported broader institutional goals. The authors used their institutional mission as the starting point for selecting assessment measures guided by the questions, "Are the collections 'responsive'? Are they 'user focused'? Are they available in the spaces 'virtual and physical' that we expect them to be?" (Duncan \& O'Gara, 2015, p. 72). While this model included several collections-related projects, the focus of the article was the development of an assessment rubric 
that evaluated disciplinary collections using multiple measures of assessment such as: student enrollment data, results from a university satisfaction survey, and collection statistics for multiple item formats; both print and electronic, text and media. Two subject areas were piloted in the first year and data snapshots of resources in those disciplinary areas were compiled for the purposes of communicating to non-library stakeholders how well these subject area collections were supporting the institutional mission (Duncan \& O’Gara, 2015).

Institutional goals also guided a collection evaluation pilot at the George Mason University Libraries. A full-time staff position was hired to support a comprehensive collection assessment program to measure progress toward achieving Carnegie Very High Research classificationpart of the university's strategic plan (Kelly, 2014). This assessment program also included multiple methods of measurement and addressed sections of the library collection by subject area. While input from all stakeholders was included during the planning of this pilot, this project was unique in that it was to be maintained by one staff position with ideally limited workload overflow to other library staff after the initial program development (Kelly, 2014).

Many libraries in higher education are assessing collections in order to reduce the physical size of the collection in response to demand for more spaces for students to work and study. The University of Arizona libraries developed a systematic process for managing their collection with the goal of repurposing existing space for independent study and group work. As a result of the focus on reallocating space in the library, the 5-year plan limited the scope to physical items in the collection and emphasized criteria for deselection (Martin, Kamada, \& Feeney, 2013). 
Similarly, the Director of Collections and the Director of Acquisitions at Kennesaw State University led the development of an on-going process to evaluate physical materials in order to "apply data-driven decision making to the selection and withdrawal of library materials" (Luther \& Guimarães, 2016, p. 182). Kennesaw State developed and piloted the first year of a continuing cycle that would systematically evaluate the entire print collection subject-by-subject every 5 years. The cycle indicates that each year different subjects come under review for systematic evaluation with year five completing a review of all print collections. Data collection and training for project coordinators, librarian liaisons, and other library staff occur over the summer, liaisons and project coordinators develop reports that synthesize the data collected during the fall, and deselection processes occur in the spring before the cycle resets in June (Luther \& Guimarães, 2016). This type of on-going collection evaluation is highly desirable not only for institutional memory, but also in supporting continuous deselection. Some academic libraries put off weeding until there is such a strong need that a large-scale project is required. Unfortunately, large scale weeding efforts can attract negative reactions from those outside the library who don't have a strong understanding of weeding as an integral part of maintaining a healthy and relevant library collection. Besides the workload implications of a large scale weeding project, regularly deselecting materials to keep a collection relevant and useful can lessen this negative perception to stakeholders outside the library (Gregory, 2011).

Many authors have also noted the significance of participating in collection assessment for the professional performance and effectiveness of liaison librarians. In Gregory's comprehensive text on collection development and management, the author discusses the importance of assessing collections to deselect materials and purchase new additions for the collection, both 
tasks generally completed by subject specialist liaison librarians (2011). In an article published in College \& Research Libraries, Kohn argues that collection evaluation is important for increasing librarian knowledge of the collections and that it improves the librarian's ability to make collections-related decisions about purchasing and deselection (2013). Further, Luther \& Guimarães acknowledge,

By engaging the liaisons so closely, the collection assessment plan aids the synthesis of facts and the creation of deep collection knowledge by the individual who needs it most: the librarians who are building the collection one resource at a time. $(2016$, p. 186)

Collection data can add to the repertoire of information subject librarians already have at their disposal. When collection data is combined with qualitative feedback from students and faculty on the impact of collections and a deep understanding of the liaison program, the subject librarian has a more complete picture of the collection. Librarians develop a better understanding of the current state of their collections and how they are meeting collection development-related goals by going through the process of assessment (Agee, 2005). Johnson from Northwestern University ties collection assessment to goal setting and argues that by discovering the strengths and weaknesses of the collection, the library can address gaps and demonstrate how the library is supporting the changing needs of a campus. Johnson adds, "Knowing the current state of its collection will help the library to see how much effort, and possibly funds, will be needed to meet new institutional goals" (2016, p. 496). 
Getting a holistic picture of the current state of a library's collections requires accurate and accessible data. When preparing for a collection assessment project, a recent inventory will ensure the library has an accurate image its current holdings (Intner, 2003; Johnson, 2016). Putting data to work that is already being gathered in the library is an ideal way to begin this process (Duncan \& O'Gara, 2015). Wilde and Level (2011) encourage libraries to maintain a pool of collections statistics that can be accessible to library staff at all times. Having this data made available annually, they argue, will improve collections decisions and save time in comparison with collecting this information on an ad hoc basis. However, it is important to recognize that statistical information across subjects has very little value without context provided by subject specialist librarians. For this reason, the authors also recommend collections data be examined by discipline so liaison librarians can provide the context needed to understand potential differences in statistics between disciplinary collections (Wilde \& Level, 2011).

Implementing a process that regularly collects and analyzes collections data can also inform library responses to the regularly occurring processes of university program reviews or external accreditations for specialized programs (Gregory, 2011). Collections assessment demonstrates the value of the collections to library stakeholders and shows evidence of how the collections support institutional goals (Duncan \& O'Gara, 2015), while also providing the context and data needed to make shifts in budgetary allocations between subjects and to advocate for additional funding for library resources to support new and/or growing programs.

\section{Background}


California State University San Marcos is a public comprehensive university with approximately 17,000 enrolled students as of Fall 2018 (CSUSM, 2018). The mission of the university highlights student learning, equitable access to education, and inclusiveness (CSUSM, 2019). Likewise, the collection development policy of the University Library prioritizes student learning and curriculum-focused research and instruction. The policy states explicitly that "Collection development directly supports the University instruction, research, and public service responsibilities, which include curriculum-related instruction, research, and other campus and regional educational objectives" (CSUSM University Library, 2008).

Within the CSUSM University Library, past collections assessment efforts had taken place on a largely ad hoc basis. In part, this was due to the fact that CSUSM is a relatively new campus (founded in 1989) and the collection had been growing in a library building where shelving space was initially abundant. Individuals or departments would occasionally recognize a need for assessment (a low-usage database or journal collection, a range of books that needed weeding, etc.) and then address the issue by gathering and analyzing the available data. However, without a systematic review process, this approach led to a rapidly aging physical collection and an inconsistent understanding of the cost-effectiveness of the library's resources. When the library went through a strategic planning process in 2014-2015, one of the strategic goals identified by the library was to "Create a systematic collection management cycle that follows a regular timeline, which will include collection evaluation, management of budget allocation, and deselection processes" (CSUSM University Library, 2015). This strategic goal was assigned to the newly-created Library Collections Committee. 


\section{Development of a Collection Management Cycle}

The Library Collections Committee was one of four new committees that were created during the strategic planning process. Each of the new committees: Collections, Space, Web \& User Experience, and Professional Development was tasked with completing work derived from the strategic plan that impacted multiple departments in the library. The committees are comprised of faculty and staff from across the library and are chaired by rotating members (typically library faculty or administrators). By using a representative model, cross-unit feedback is built into the committee structure and lessens the risk of creating processes and programs that neglect any potential stakeholder expertise and concerns. At other institutions, the creation of an ongoing process for collections management has been led by individual staff (Kelly, 2014; Kohn, 2013) or librarians in the areas of technical services or assessment (Duncan \& O'Gara, 2015; Luther \& Guimarães, 2016). One of the challenges of drafting an on-going process for collection assessment by committee was that the group had to propose and create workflows that would be implemented by several departments across the library. To address this challenge, all committee work was drafted with the input of individuals from all library departments, approved through a consensus model, and required final approval from a team composed of the department heads and library administration. Library Administration (the Dean and Associate Dean) then referred the proposed collection assessment project to relevant library departments for implementation. For the Collection Management Cycle (CMC), the relevant implementation departments included: Library Technology and Innovation, Collection Management and Technical Services, User Services, and Library Teaching and Learning. 
Prior to drafting the $\mathrm{CMC}$, a small working group from within the Collections Committee created a purpose document to guide the development of the cycle [Appendix A]. This document tied the project to the library's mission and strategic plan, helped to define the scope, and provided initial directions for the committee members to commence their work. The purpose document highlighted the library's goals of supporting the wise stewardship of public funds and increasing knowledge of the existing collection to better inform collections-related decisions.

The working group conducted an environmental scan through an email survey which was sent to similar sized institutions and to other universities within the California State University system (there are 23 individual universities within the CSU). Simultaneous to conducting the environmental scan, the working group reviewed the literature to learn collection management best practices and trends. This step was especially important due to the nature of working on this project by committee; many of the committee members did not have any formal responsibility for or experience with collection management. After creating an initial draft of the CMC, representatives from the committee attended meetings of all library departments that would be involved in the new processes to solicit feedback and answer questions regarding the proposal.

\section{The Collection Management Cycle - Methodology and Timeline}

The final proposed methodology [Appendix B] was informed by the purpose document [Appendix A], the responses solicited through the environmental scan, the literature review, and stakeholder feedback. Additionally, the methodology drew heavily from the recommendations put forth by Gregory (2011), which includes: creating a data snapshot of the collection using both quantitative and qualitative data; focusing on the collection in smaller, more manageable 
sections rather than all at once; and developing a plan of action for the future of the collection based on the assessment, including recommendations for deselection and for new resource acquisition. The final 16-month cycle [Appendix C] aligns with the university's program review cycle in which all academic programs are reviewed every five years. As a part of these program reviews, liaison librarians put together reports on relevant library collections and librarian integration into the program being reviewed. Therefore, aligning the CMC with already scheduled reporting requirements for the liaison librarians helps minimize extra workload.

The CMC includes the following five components (listed with each library department where the work takes place):

- Targeted inventory on LC call number ranges reflecting the subjects under review for the year (User Services)

- Data collection and preparation of reports on all library resources falling within the subject area being reviewed (Collections Management and Technical Services)

- Shelf observations to assess physical collection wear (Liaison librarians - Library Teaching and Learning)

- Creation of assessment/recommendation reports and sharing those reports with library administration and other library departments (Liaison librarians - Library Teaching and Learning)

- Procedural deselection processes based on the assessment reports created by liaison librarians (Collections Management and Technical Services) 
It is important to note that the liaison librarians for the program/subject under review are the responsible parties for creating the final assessment reports and recommendations. As selectors for the program/subject, the liaisons are the primary ties to the curriculum and disciplinary faculty. This entails keeping up-to-date with the specific foci of the classes being taught in their liaison areas and the research areas of disciplinary faculty. As such, resource recommendations (whether for new item acquisition or deselection) are driven by the liaisons to maintain a strong tie to the curriculum.

\section{Pilot Year Plans}

The CSUSM Library will implement a pilot year of the CMC in which a small set of programs undergoing program review will be taken though the new cycle. The pilot year will provide the space and time for relevant library departments to work through and make changes to procedures and report structures before the full implementation. The liaison librarians participating in the pilot were also Collections Committee members during the development of the cycle and will provide continuity following the pilot year by sharing assessment reports and documentation with other liaison librarians as a model. The subject liaisons will also begin the creation of a CMC manual, a living document that will record practices and procedures that are not reflected in the existing CMC methodology document [Appendix B], ensuring knowledge generated through the process won't be lost year to year as new library faculty and staff participate.

\section{Conclusion}

The development of an on-going Collection Management Cycle at the CSU San Marcos University Library represents a significant shift from past practices. There had been no consistent 
collections evaluation in the library before the $\mathrm{CMC}$, with collections assessment occurring on an ad hoc basis. The idea for creating a more consistent approach to collections management came from a library-wide strategic planning process. The creation of the cycle itself also came from a committee with wide representation from across the library. Having participation and input from all library departments starting from the inception of the idea was crucial to the buy-in received from library faculty and staff on implementing this very real change in the library.

The Library Collections Committee developed the CMC by conducting a literature review on best practices in library collections assessment and on the successful implementation of similar projects published in the literature. The committee also learned about the practices of similarsized institutions and other universities in the CSU system through an environmental scan. The CMC assesses the entire library collection subject by subject, with every subject area reviewed every five years. The cycle maps the timing of the subjects under review to the University Academic Master Plan for program review. By taking advantage of the timing of program reviews, duplicate work in collection assessment is reduced and collection recommendations can be made with considerations to accreditation and growth of, or changes to, academic programs. A yearly timeline of when certain activities related to the cycle occur ensures there are no surprises for library departments and supports a collective understanding of how each department contributes to assessment of the library collections.

For other academic institutions that are considering implementing a formal process to assess library collections, it is recommended that the goals of the library and institution be at the forefront of the project. Alignment with institutional goals and/or strategic directions is vital for 
receiving administrative support for such a large-scale project. Aligning the timing of the process with outward facing collections reporting activities can help minimize new workload for library staff and improve the depth and impact of external reporting activities.

The creation of an on-going Collection Management Cycle through a process that prioritized library-wide input and stakeholder feedback was a major accomplishment for the CSUSM University Library. There were, however, some timing-related issues encountered during development that slowed down the process. While the Library Collections Committee had representation from all departments, there was still a gap in knowledge in terms of work that would have to happen on the ground before the $\mathrm{CMC}$ launched. The development of data reports on the collections that would be broken down by subject area and reflect multiple resource types was a task that was more complicated and took more time than the committee foresaw. For other institutions undergoing a similar process, the authors recommend receiving feedback not only from all departments participating in the process, but also from the individuals who will carry out specific tasks. This would have allowed the committee to anticipate a more realistic timeline to launching the new assessment cycle. Finally, it is also recommended that an individual or a committee is charged with the on-going facilitation of the process. In this case, the Library Collections Committee was only tasked with developing the plan, with the on-going tasks communicated and assigned to department heads. Implementation would have been a smoother process had there been a group or individual in charge of facilitating the schedule reflected in the timeline [Appendix C].

Declaration of interest statement: the authors report no potential conflicts of interest. 


\section{References}

ACRL Research Planning and Review Committee. (2016). 2016 top trends in academic libraries: A review of the trends and issues affecting academic libraries in higher education. Retrieved from https://crln.acrl.org/index.php/crlnews/article/view/9505

Agee, J. (2005). Collection evaluation: a foundation for collection development. Collection Building, 24(3), 92-95. https://doi.org/10.1108/01604950510608267

California State University San Marcos. (2018, August 23). New Academic Year Opens with 17,000 Students. Retrieved May 6, 2019, from CSUSM News Center website: https://news.csusm.edu/back-to-school-2018/

California State University San Marcos. (2019). Mission, Vision \& Values. Retrieved January 30, 2019, from https://www.csusm.edu/about/facts/mission.html

California State University San Marcos, University Library. (2008, October 13). Collection Development Policy. Retrieved January 30, 2018, from https://biblio.csusm.edu/content/collection-development-policy

California State University San Marcos, University Library. (2015). Strategic Plan 2015-2020. Retrieved January 30, 2018, from https://biblio.csusm.edu/content/strategic-plan

Duncan, C. J., \& O’Gara, G. M. (2015). Building holistic and agile collection development and assessment. Performance Measurement and Metrics, 16(1), 62-85. https://doi.org/10.1108/PMM-12-2014-0041

Gregory, V. L. (2011). Assessment and evaluation of the collection, including deselection. In Collection Development and Management for 21st Century Library Collections: An Introduction (1 edition, pp. 113-130). New York: Neal-Schuman Publishers, Inc. 
Harker, K. R., \& Klein, J. (2016). Collection assessment (SPEC Kit 352). Retrieved from Association of Research Libraries website: http://publications.arl.org/CollectionAssessment-SPEC-Kit-352/

Intner, S. (2003). Making your collections work for you: Collection evaluation myths \& realities. Library Collections, Acquisitions, and Technical Services, 27(3), 339-350.

Johnson, Q. (2016). Moving from Analysis to Assessment: Strategic Assessment of Library Collections. Journal of Library Administration, 56(4), 488-498.

Kelly, M. (2014). Applying the tiers of assessment: A holistic and systematic approach to assessing library collections. The Journal of Academic Librarianship, 40(6), 585-591.

Kohn, K. C. (2013). Usage-based collection evaluation with a curricular focus. College \& Research Libraries, 74(1), 85-97.

Luther, M., \& Guimarães, A. (2016). Applying the Principles of Total Library Assessment to Inform Sustainable Collection Development. Paper presented at the Library Assessment Conference, Houston, Texas. Retrieved from https://works.bepress.com/michael_luther/20/

Martin, J., Kamada, H., \& Feeney, M. (2013). A systematic plan for managing physical collections at the University of Arizona libraries. Collection Management, 38(3), 226242.

Wilde, M., \& Level, A. (2011). How to drink from a fire hose without drowning: Collection assessment in a numbers-driven environment. Collection Management, 36(4), 217-236. 
Appendix A.

\section{Statement of Purpose \\ CSUSM University Library Collection Management Cycle}

“The University Library is an essential partner in teaching and learning, research, and community engagement at CSUSM" (University Library Mission Statement). The Library supports the overall mission of the University, which "focuses on the student as an active participant in the learning process." The values of innovation and responsiveness, shared by both the University and the Library, are expressed through the continuous improvement of library resources and services to meet the changing requirements of the information environment and needs of Library users.

As part of the University Library Strategic Plan, the Collections Committee was tasked with creating a systematic collection management cycle that follows a regular timeline, which will include collection evaluation, management of budget allocation, and deselection processes. This goal is part of Strategic Direction 2: Information resources provided by the Library on behalf of the campus community will facilitate innovative, student centered teaching and learning.

The purpose of this collection management cycle is to:

- facilitate an ongoing process of assessment and evaluation to ensure library collections are current and relevant to Library users, with special attention paid to curricularly-related needs, 
- increase accountability and the wise stewardship of public funds that support the collections,

- better understand current library holdings to address gaps and inform collections decisions,

- ensure regular processes and procedures are in place to provide adequate time for collections-related decision making,

- anticipate areas of collection development that support the future curriculum of Cal State San Marcos. 
Appendix B.

\section{CSUSM Library Collection Management Cycle}

Summer: Inventory completed and data compiled for each program/subject under review

- User Services will complete targeted inventory focusing on the LC call number ranges for the programs under review in the upcoming academic year.

- Reports from User Services will include:

- Physical item circulation statistics (all formats) with an emphasis of frequency of use and last used date

- Media site viewing statistics

- Course Reserves statistics

- Interlibrary Loan requests

- Reports from Collection Management \& Technical Services will include:

- Physical item statistics (all formats)

- Title count

- Median age of items in collection (excluding physical periodicals)

- Standing orders

- Title list

- On-going cost per title

- Summary of electronic journal resources (including subject-specific and multidisciplinary databases, electronic journal packages, and individual journal subscriptions not part of a larger package) 
- Databases and journal package data

- Total Searches, Result Clicks, and Record Views

- Cost per record view

- Individual journal data (not part of a larger package)

- Number of Successful Full-Text Article Requests

- Total Searches Run

- Cost per successful article requests

- Summary of e-book and streaming video collections and individually purchased e-books or streaming videos

- E-books

- Number of Successful Title Requests - entire book

- Number of Successful Section Requests - chapter

- Access Denied to Content Items

- Cost per use

- Streaming videos

- Number of Successful Multimedia Full Content Unit Requests

- Standardized cover letter that includes some context and analysis of the electronic holdings, including:

- Who is paying for the electronic collections? (Library budget/Extended Learning/other)

- Cost of all electronic collections included in report.

- Any history available on the acquisition of these resources.

- Data gathered by subject specialists will include: 
- The most recent year's syllabi for all courses in the program.

- List of newly approved programs and courses.

Fall: Review by Subject Specialists

- Subject Specialists:

- Review data reports.

- Make database renewal recommendations.

Spring: Development of Assessment Reports and Deselection Processes

- Subject Specialists:

- May request additional customized reports of library materials from User Services to facilitate deselection decisions.

- Conduct shelf observations to assess collection wear.

- Develop assessment reports of their subject area collections to make available to Library Administration, CMTS, User Services, and the Library Collections Committee. These reports will include:

- A list of titles for deselection.

- The strengths and weaknesses of the collection in relation to the current and future program curriculum.

- Collection development goals for the next 5 years.

- Recommendations for canceling packages/databases and/or the selection of new resources (both electronic and physical). Recommendations for 
new resources should also be added to the "Wish List for New Subscriptions" or the "Wish List for One Time Purchases."

- Budgetary implications of recommendations for new resources. CMTS will assist in requesting quotes from vendors.

- User Services and CMTS receive the reports and begin deselection processes.

- Subject Specialists will prioritize the wish list after it is updated each spring with the guidance of the Head of CMTS.

- If there are funds available to allocate to new resources, the Collections Committee recommends Subject Specialists elect a subcommittee responsible for the prioritization and selection of new resources. The subcommittee will be made up of two selector librarians, the TAL liaison to CMTS, the Head of CMTS, and one library staff volunteer from CMTS. Terms will last 2 years and be staggered. Elections will take place in Fall through Library Faculty Council and will include all selectors and CMTS librarians unless individuals opt out. The ballot will also include staff members who have volunteered to be on the subcommittee from CMTS. This group will use the criteria established by Subject Specialists to make recommendations on the allocation of available funds to the Library Dean. If there are no available funds, the subcommittee will not meet. 
Appendix C.

Inventory Timeline - Collection Management Cycle - Program Review Timeline

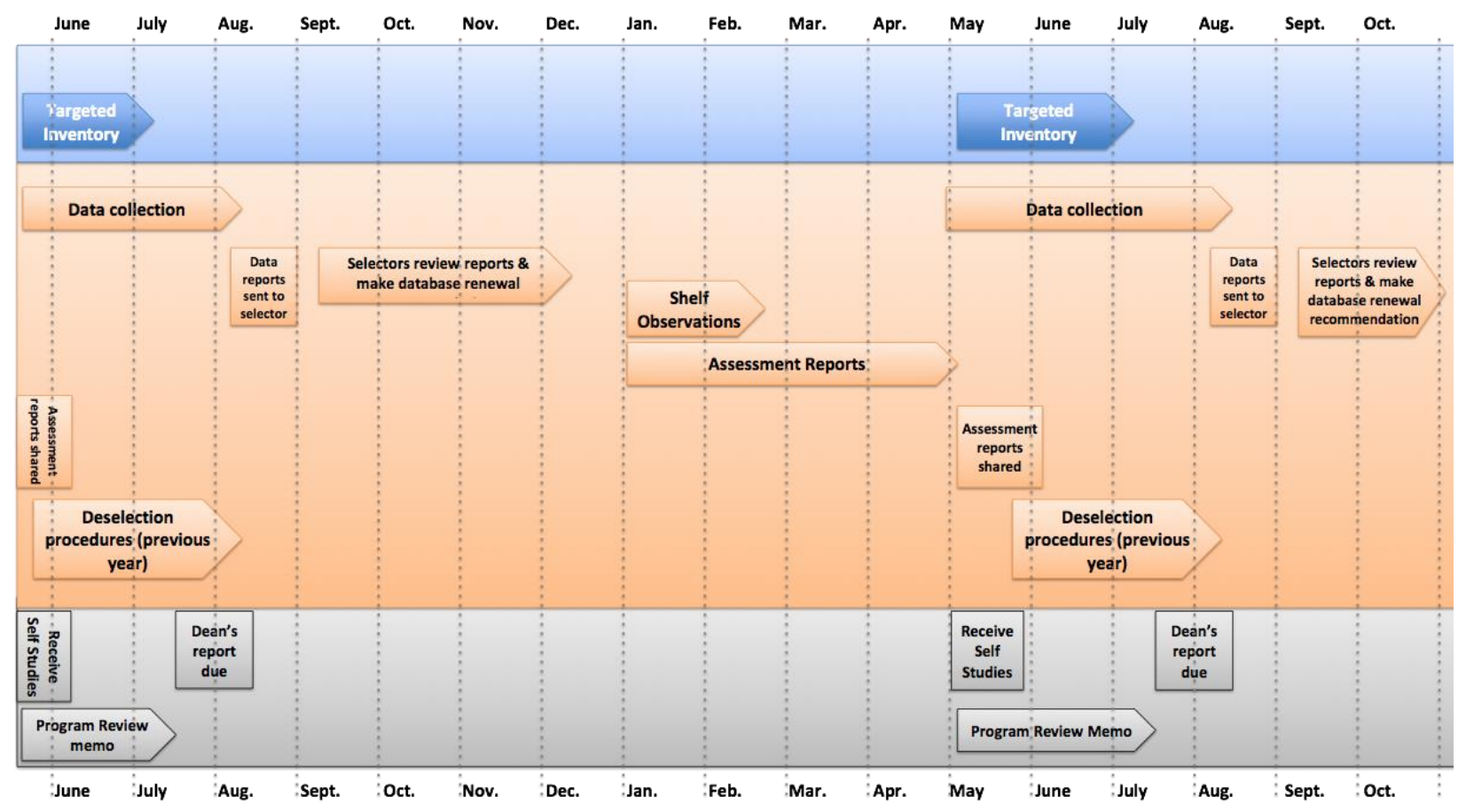

